\title{
PSEUDOMALE BEHAVIOUR AND SPONTANEOUS MASGULINIZATION IN THE ALL-FEMALE TELEOST POECILIA FORMOSA (TELEOSTEI: POEGILIIDAE)
}

\author{
by
}

\begin{abstract}
INGO SCHLUPP',5), JAKOB PARZEFALL'1), JORG T. EPPLEN' ${ }^{2}$ ), INDRAJIT NANDA $^{3}$ ), MICHAEL SCHMID ${ }^{3}$ ) and MANFRED SGHARTL $4,6,7,8$ )
\end{abstract}

(' Zoologisches Institut und Zoologisches Museum der Universität Hamburg, MartinLuther-King Platz 3, D-2000 Hamburg 13, F.R.G. ${ }^{2}$ Max-Planck-Institut für Psychiatrie, Am Klopferspitz 18a, D-8033 Martinsried, F.R.G. ${ }^{3}$ Institut für Humangenetik der Universität, Koellikerstraße 2, D-8700 Würzburg, F.R.G. ${ }^{4}$ Genzentrum, Max-Planck-Institut für Biochemie, Am Klopferspitz 18a, D-8033 Martinsried, F.R.G.)

(Acc. 10-VII-1992)

\begin{abstract}
Pseudosexual behaviour is a rare phenomenon associated with unisexuality in vertebrates. In the gynogenetic, all-female teleost Poecilia formosa, rare individuals occur that resemble males of closely related gonochoristic species both in behaviour and external morphology. These masculinized gynogens and normal gynogens are members of the same clone, as demonstrated by DNA-fingerprinting. The behaviour of these masculinized gynogens is described and compared to the behaviour of the gonochoristic species Poecilia mexicana, $P$. latipinna and their hybrid as well as androgen-treated individuals of $P$. formosa. No statistically significant differences were found between masculinized gynogens and hormonetreated individuals nor between the gonochoristic $P$. mexicana and $P$. latipinna males. Differences exist between gonochoristic and unisexual species. Possible causes and effects of masculinized gynogens are discussed.
\end{abstract}

\section{Introduction}

The evolution and maintenance of sexual reproduction is one of the most challenging questions in modern biology. Unisexual organisms can serve

5) Address from March 1993: University of Texas at Austin, Department of Zoology, Austin, Texas 78712 , U.S.A.

6) Present address: Theodor Boveri Institut für Biowissenschaften, Am Hubland, D-8700 Würzburg, F.R.G.

7) We dedicate this paper to the late G. Peters.

8) We thank M. Irentschiuk, W. Kambach, A. Schlupp and D. Teege for technical assistance and animal care. M. Hänel drew the figures. A. EgGERs, J. LAMprecht, D. CREWs and two anonymous referees provided critical comments on the manuscripts. S. BEDDig corrected the English. We thank the DFG for financial support (PAl48/10-1). This article is in part based on a doctoral study by I.S. in the Faculty of Biology, University of Hamburg. 
here as uniquely suited models (CREws, 1989). The gynogenetic allfemale poeciliid fish Poecilia formosa (GrRard, 1859) is one of the few vertebrates (VRIJENHOEK et al., 1989) with a reproductive mode different from the usual gonochoristic pattern (HubBs \& HubBs, 1932). Females produce diploid eggs. Embryogenesis is triggered by sperm of males of the closely related gonochoristic species $P$. mexicana STEINDachner, 1863 or $P$. latipinna (LE SuEur, 1821). Normally, males contribute nothing to the genome of the offspring: inheritance is strictly maternal. $P$. latipinna and $P$. mexicana are not only the host species in this mating-system (SCHLUPP et al., 1991) but also most probably the parental species of this natural hybrid species (Hubbs \& Hubbs, 1932; Turner, 1982; Avise et al., 1991).

Exceptional individuals of $P$. formosa which resembled the phenotype of males of closely related gonochoristic species were first mentioned in a paper by HubBs \& HubBs (1932), in which they described $P$. formosa as a gynogenetic species. Later HubBs et al. (1959) first described the morphology of a 'phenotypic male' of $P$. formosa. Males of the live-bearing genus Poecilia are recognized by their copulatory organ, the gonopodium, a modified anal fin. All $P$. formosa reported as 'males' had a gonopodium and some of them were reported to show aspects of male-typical behaviour (Table 1). Using androgen treatments it has already been possible to induce artificial masculinization in all-female P. formosa (ScharTl et al., 1991; Turner \& Steeves, 1989).

In one of our laboratory stocks of gynogenetic $P$. formosa, occasionally individuals occur spontaneously with not only the general appearance, but also with the male-typical behaviour of the genus.

In the present paper we compare spontaneously masculinized gynogens to androgen treated individuals and to gonochoristic males of $P$. latipinna, $P$. mexicana and their interspecific hybrid.

We used several techniques to address the following questions: are masculinized gynogens and normal gynogens members of the same clone? Is the spontaneous masculinization induced by free androgens in the aquarium water? Is the behaviour of the masculinized gynogens comparable to the behaviour of hormone-induced 'males' of $P$. formosa? Do masculinized gynogens show behaviour patterns of the presumed parental species, especially the elaborate male courtship display of $P$. latipinna? Do males of the laboratory produced hybrid of $P$. mexicana and $P$. latipinna behave more like masculinized gynogens or their gonochoristic parents?

In preliminary experiments we tried to evaluate effects of masculinized gynogens and factors responsible for the observed masculinization. 


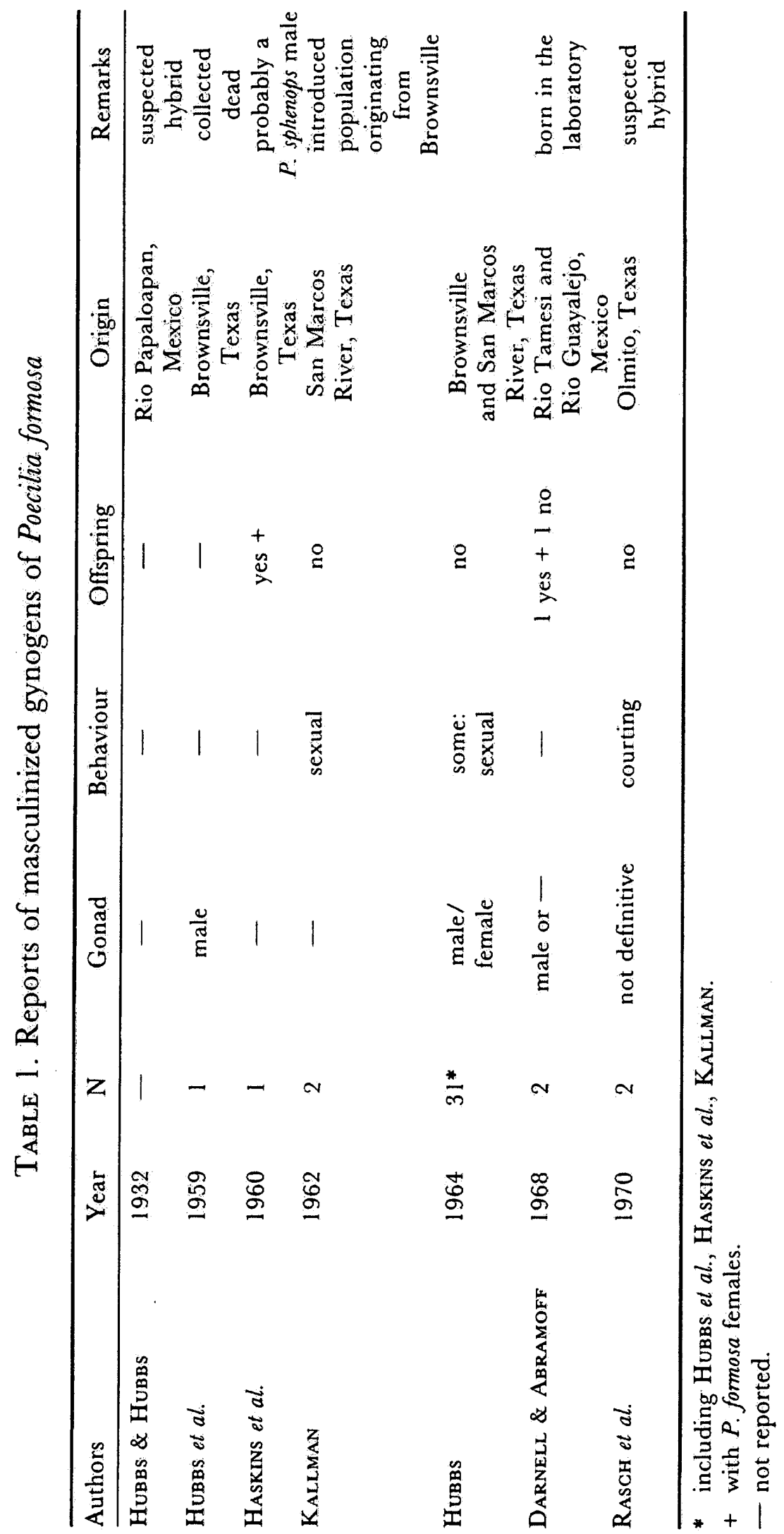




\section{Material and methods}

General housing conditions.

The fish were kept in large tanks at a constant temperature of $25-27^{\circ} \mathrm{C}$ in a $12: 12$ light/dark cycle with a salinity of approx. 5\%o. P. formosa were bred with ornamental black molly males in order to detect any transmission of male genes by black spotting of the offspring (Haskins et al., 1960; Schultz \& Kallman, 1968; Balsano et al., 1989; Rasch \& Balsano, 1989). Fish were fed with commercially available dry food twice a day. Tubifex and Cladocerans were added depending on the season. Young fish were reared with brine shrimp nauplia. The origin of the stocks was described by SchlupP et al. (1991).

\section{Test animals.}

Five types of males were examined (Table 2). To distinguish them we use the following terms: masculinized gynogens are spontaneously occuring $P$. formosa females with male-like behaviour and habitus. Hormone-males are $P$. formosa gynogens treated with testosterone. $\mathrm{F}_{1}$-males originate from acrossing experiment with $P$. latipinna and $P$. mexicana. $P$. latipinna and $P$. mexicana males originate from gonochoristic species. While we distinguished 5 types of males, the females tested with masculinized gynogens and hormone-males were of the same type $(P$. formosa), so that only 4 groups go into statistical analysis.

\section{TABLE 2. Combinations used in the behavioural tests}

\begin{tabular}{ccr}
\hline male & female & $\mathrm{N}$ \\
\hline Masculinized gynogen (P. formosa) & gynogen $(P$. formosa $)$ & 27 \\
Hormone-male $(P$. formosa) & gynogen $(P$. formosa $)$ & 9 \\
$P$. mexicana & $P$.mexicana & 11 \\
$P$. latipinna & $P$. latipinna & 8 \\
F $_{1}$-hybrid & F $_{1}$-hybrid & 6
\end{tabular}

$\mathrm{N}=$ number of fish used.

\section{Behavioural tests.}

For the behavioural tests one male and one female fish were chosen randomly from a stock tank and placed into the two equal sized compartments of a 251 aquarium. The compartments were separated by opaque partitions. After acclimatisation for $24 \mathrm{~h}$ the opaque partition was removed and the interactions of the two fish were recorded using an eventrecorder for 15 minutes. All pairs were tested twice in an experiment.

Three types of behaviour were recorded for all types of males. 'Following' was defined as every approach and staying in close contact with a female, mostly approaching the female from behind and often followed by 'Nipping', defined as contact of the males mouth region with the females genital region. 'Copulation attempts' or copulatory movements are all male attempts to thrust its gonopodium into the female genital opening. A related element of sexual behaviour is 'Gonopodial thrusting', a copulation like movement of the gonopodium, which was not recorded because it was too infrequent. An elaborate 'Courtship display', performed in front of the female, is only known from P. latipinna (PARzefall, 1969; see Fig. I in Schlupp et al., 1991).

All types of females can respond to every male behaviour by accepting the male and 'Remaining motionless' or reject the male aggressively ('Rejection') or flee from the male 
('Flight'). The first type of behaviour indicates sexual cooperation, while the other two types are common in situations in which the female is not willing to copulate. Males show all kinds of sexual behaviour towards females all through the female sexual cycle (PARZEFALL, 1973). The activity level, however, is much higher, if female are in attractive status. Therefore, females were in non-attractive status (PARzefall, 1973) so that scores were not influenced by female receptivity.

\section{Hormonal masculinization.}

To obtain experimentally induced phenotypic males, juvenile $P$. formosa of a truly all-female clone, in which we never observed masculinized gynogens, were exposed to $1 \mathrm{mg}$ methyltestosterone per liter aquarium water for $24 \mathrm{~h}$ once a week (Dzwillo, 1962). After 4-6 treatments the fish had developed a gonopodium and clearly changed into 'phenotypic males'. To distinguish the spontaneously occurring masculinized gynogens, we call them hormone-males.

\section{DNA-fingerprinting.}

For DNA-fingerprint analysis DNA was extracted from pooled organs of single adult $P$. formosa gynogens as described (SCHARTL, 1988). For analysis of DNA fingerprints, in gel hybridization of restriction enzyme (Hae III and Hinf I) digested genomic DNA to radioactively labelled oligonucleotide probes was performed as described (NANDA et al., 1990). The following probes were used under stringent hybridisation and washing conditions: $(\mathrm{GGAT})_{4},(\mathrm{GACA})_{4},(\mathrm{GATA})_{4},(\mathrm{GAA})_{6}$ and $(\mathrm{CA})_{8}$.

\section{Research of inducting factors.}

Since the masculinizing effect of testosterone is known (see above), we wanted to find out whether free testosterone was present in the stock tanks in which the spontaneous masculinization occurred. To monitor presence of androgenic steroids females of Girardinus metallicus, homozygous for the Vn-gene (Ventral nigra), were added to the stock tanks. This was done twice. If androgenic steroids above a concentration level of $10^{-9} \mathrm{M}$ are present in the water, these females develop the male-specific Vn-macromelanophore pattern as early as 5-7 days after introduction (Scharrl et al., 1982).

\section{Research of possible effects.}

To test whether masculinized gynogens were able to induce embryogenesis in normal gynogens, one masculinized gynogen was kept in a $25 \mathrm{l}$ aquarium together with three normal gynogens $(\mathrm{N}=4)$. In a second experiment the masculinized gynogen was replaced by a non-functional black molly male, the gonopodium of which had been removed. This made sperm transfer impossible, but did not hinder other sexual behaviour $(\mathrm{N}=2)$. As a control we used one black molly male together with three normal gynogens $(N=2)$.

\section{Statistical analysis.}

For statistical analysis we used the non-parametric Kruskal-Wallis one-way ANOVA (Htest) to state whether the observed variance between all groups could be attributed to one statistical population. If $\mathrm{H}_{0}$ was rejected we used $\mathrm{k}$-sample pairwise tests (after CoNNover in BorTZ et al., 1990) to compare differences between groups. Female reactivity was expressed as percent of total activity of males for each type of reaction, because absolute numbers depend on the number of actions directed at the female. 


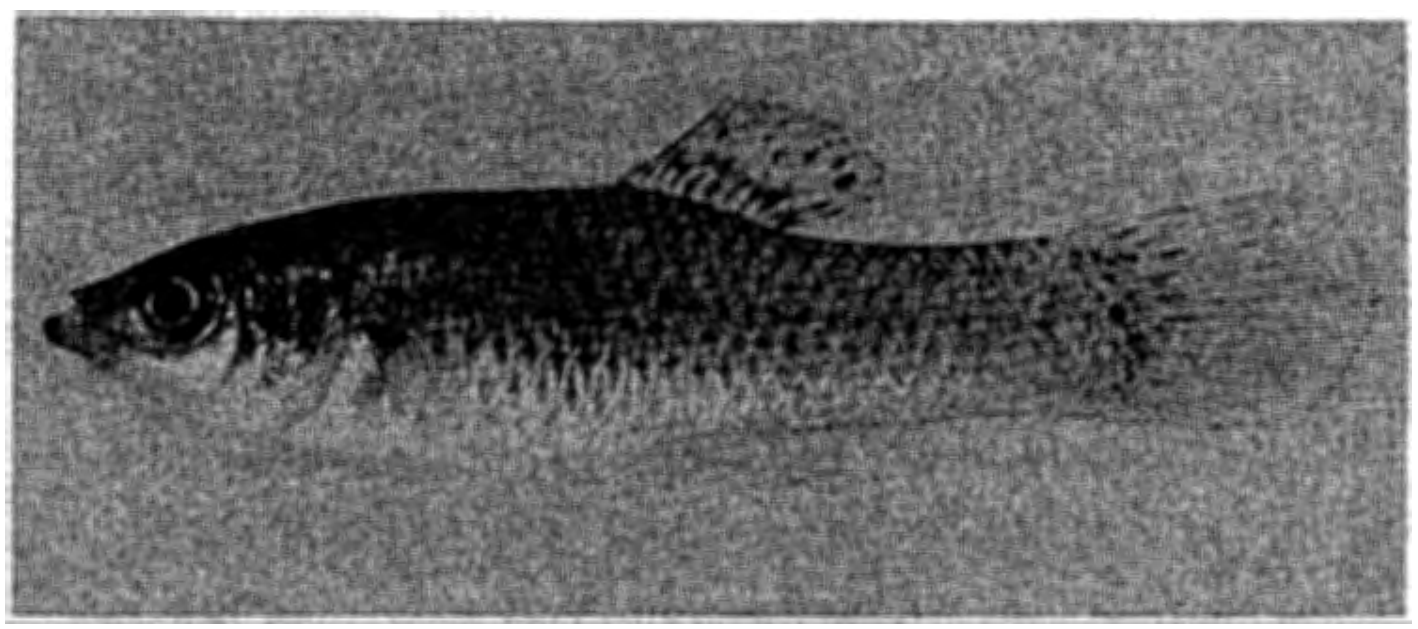

Fig. 1. Spontaneously masculinized gynogen of Poecilia formosa.

\section{Results}

External morphology of masculinized gynogens.

The external morphology of masculinized gynogens resembled the typical appearance of males of the closely related species of shortfin mollies of the subgenus Mollienesia (sensu Miller, 1983) (Fig. 1) as well as hormonally induced males of $P$. formosa (Schartl et al., 1991). The slender body shape and more intense colouration is also typical for males of Mollienesia. A gonopodium was always present, but was sometimes incompletely developed (Fig. 2a, b). Those gonopodia resembled the transforming anal fin of immature males of Mollienesia. In the most completely developed gonopodia, only the extent of the gonopodial palp on ray 3 differed from that of $P$. mexicana, P. latipinna and $\mathrm{F}_{1}$-males (Fig. 2c). For comparison Fig. $2 \mathrm{~d}$ shows a typical female anal fin.

Behaviour of masculinized gynogens and males.

Masculinized gynogens of $P$. formosa displayed several behaviour patterns that are otherwise known only from males. In an all-female form this finding is surprising, because the genes coding for male traits are obviously dispensable. 'Following' and 'Nipping' were present in a way typical for both $P$. mexicana and $P$. latipinna males. 'Gonopodial thrusting' was absent and 'Copulation attempts' were rare and incomplete. Apparently the males were not able to move their gonopodium into a forward position. This might be due to lack of the specific muscles. 
SCHLUPP, PARZEFALL, EPPLEN, NANDA, SCHMID \& SCHARTL
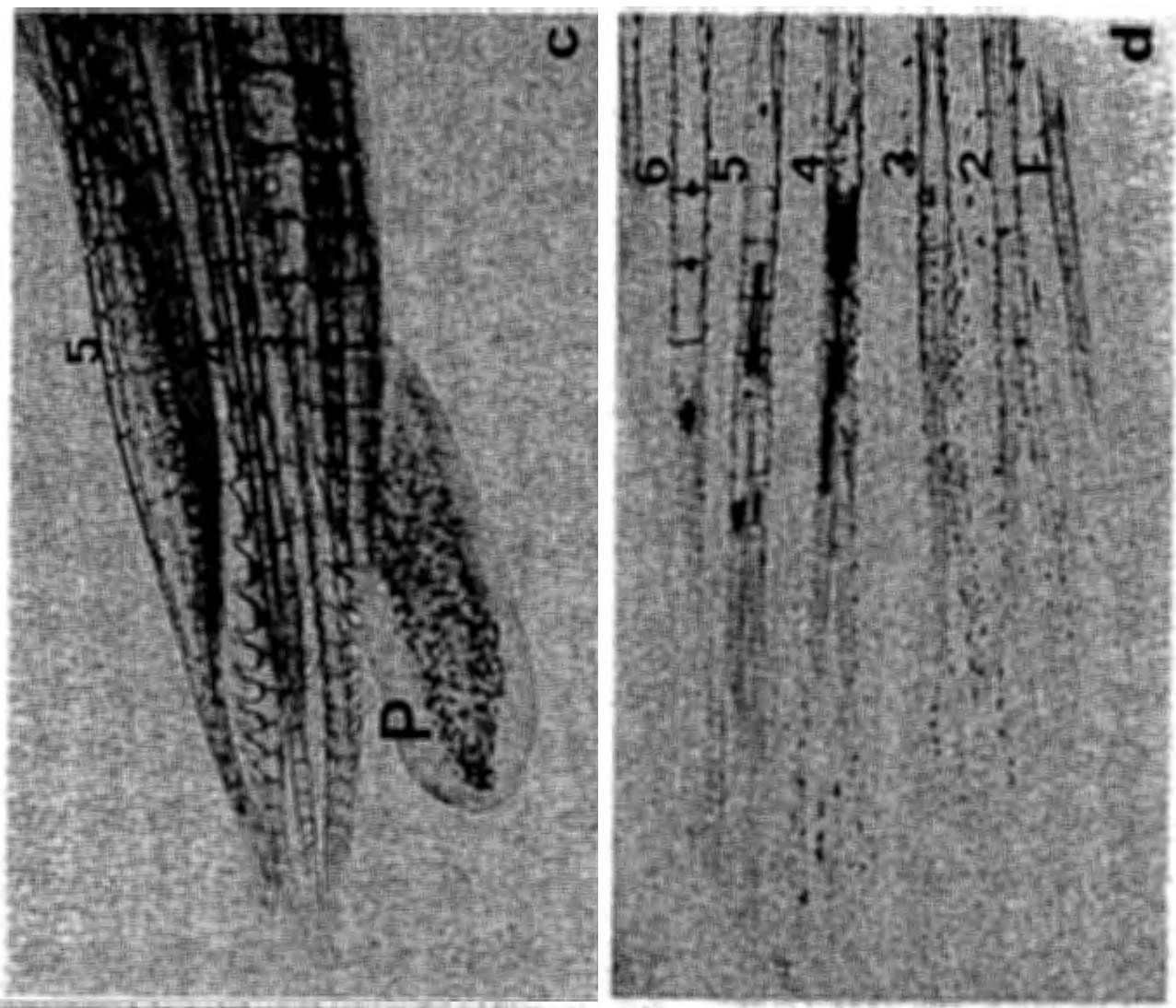

㐫造

อ

产运焉

․․ㄹ

है

的

용

สิ

象

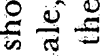

ㄷㅇ

돈

(3)

$\varepsilon \Xi$

बर है

ส

冚

氖
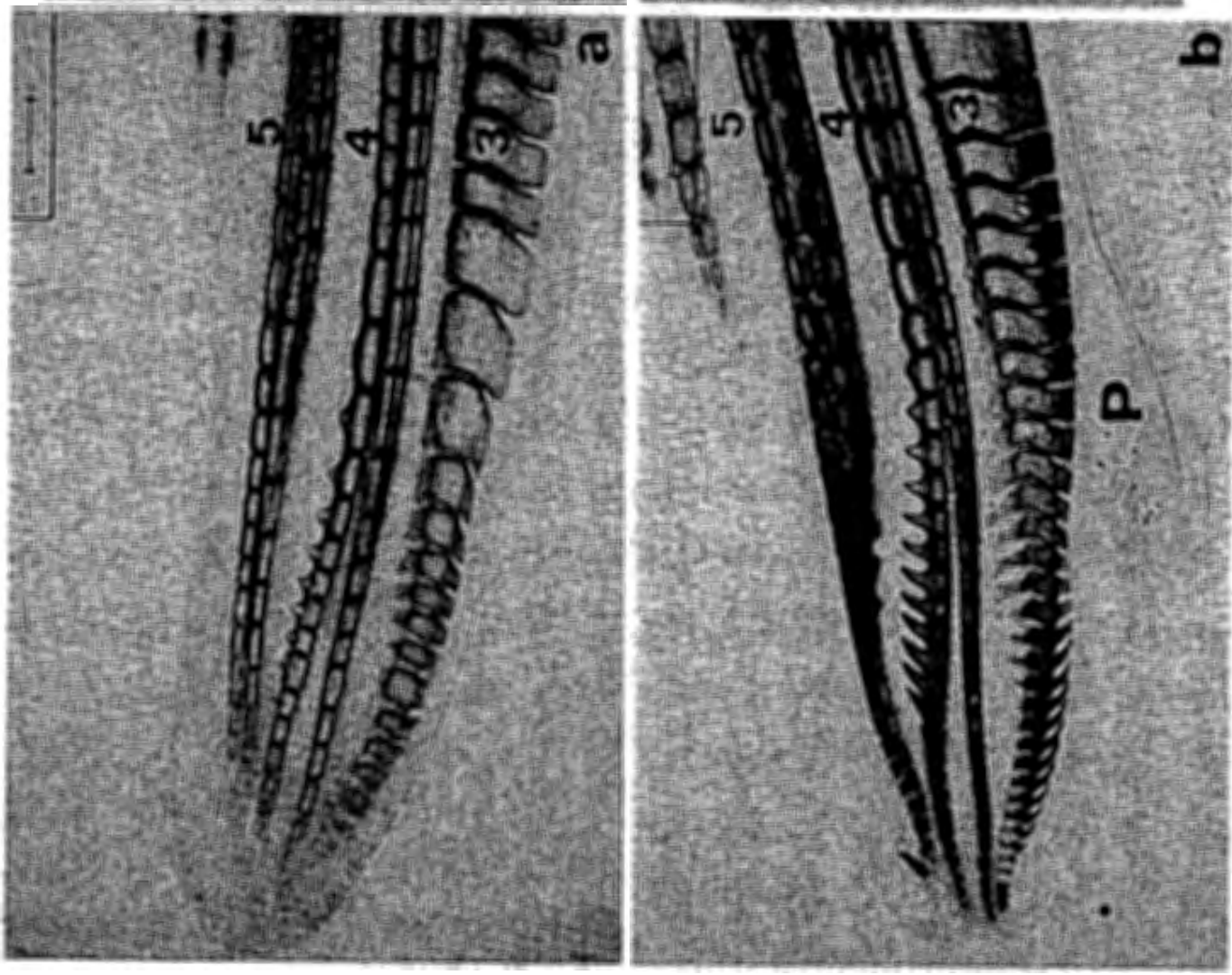

สㅇํㅇ

हี

요

풍

氙造㟧

० का

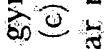

정

品

륵

of

$\varepsilon \stackrel{N}{0}$

词

os

$\exists=$

过

की

สํำ

중

응

E.

o

Ni。

串 
These types of behaviour are never shown by gonochoristic females and normal gonogens. We classify this as pseudosexual behaviour, i.e. malelike behaviour, shown by individuals that are otherwise female (Grews, 1988). This definition does not include heterotypical behaviour, i.e. behaviour usually displayed by the opposite sex, like mounting of female guinea pigs (Goy \& Roy, 1991). Heterotypical behaviour is confined to gonochoristic species.

Courtship display as known from $P$. latipinna was absent in masculinized gynogens. This was also true for $\mathrm{F}_{1}$-males, although their father was a $P$. latipinna male. Occasionally occurring postures in front of the female shown by masculinized gynogens that resembled an imcomplete courtship display could not be distinguished from aggressive display.

The only novel behaviour we observed in masculinized gynogens was a slow crossing underneath the female with fin contact. We never observed this in $P$. mexicana or P. latipinna. The function of this remains unknown.

Statistical analysis.

Mean and median values for all types of male behaviour were always higher in $P$. mexicana and $P$. latipinna, than in masculinized gynogens or hormone-males (Fig. 3a-c). Masculinized gynogens and hormone-males appeared to be more or less similar. $F_{1}$ males have the activity level of gonochoristic males. They were not intermediate in behaviour (Fig. 3a-c).

Using the Kruskall-Wallis $\mathrm{H}$-test we tested for general differences between groups. All results were significant, indicating that the groups were not samples of the same statistical population (Table 3). After this we used k-sample pairwise comparisons to test which groups were different from each other (Fig. 3a-c). Most important is that masculinized gynogens and hormone-males never show statistically significant differences. The same is true for $P$. latipinna and $P$. mexicana. These gonochoristic species are more similar to each other than to masculinized gynogens or hormone-males. No statistically significant differences could be found between $\mathrm{F}_{1}$-males and $P$. latipinna and $P$. mexicana males.

Significant differences in 'Following' are only found between $F_{1}$-males and masculinized gynogens and $F_{1}$-males and hormone-males (Fig. $3 a$ ). In 'Nipping' and 'Copulation attempts' all pairwise tests including either masculinized gynogens or hormone-males yielded statistically significant results (Fig. 3b, c). This clearly divides the inspected types of males into two groups: masculinized gynogens and hormone-males form one group and the gonochoristic P. mexicana, P. latipinna and $\mathrm{F}_{1}$-males form the other one. 


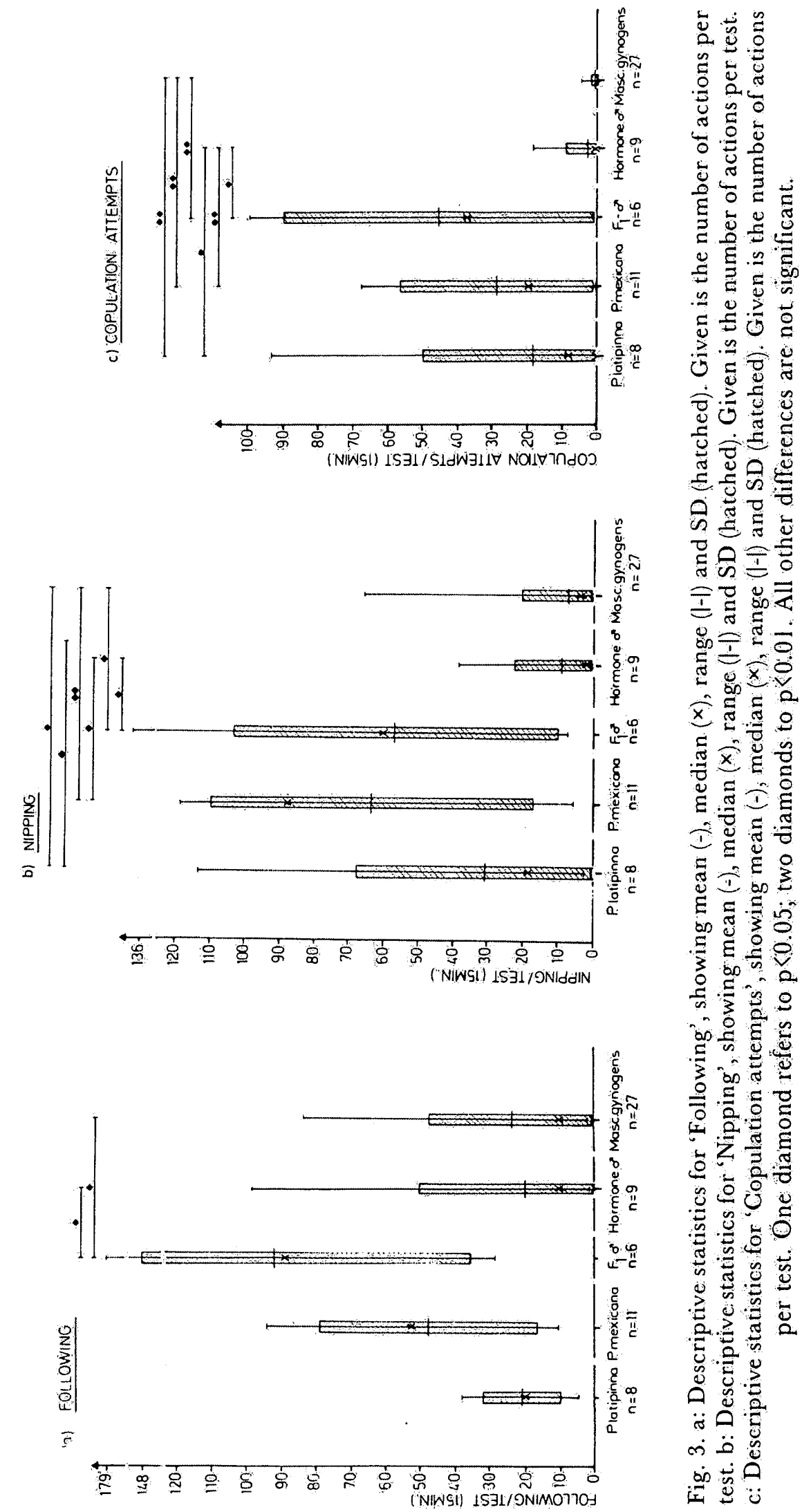


TABLE 3. Kruskal-Wallis $\mathrm{H}$ - Tests

\begin{tabular}{cccccc}
\hline sex & Behaviour & H-value & df & p-Value & N \\
\hline male & Following & 17.35 & 4 & 0.0017 & 61 \\
male & Nipping & 26.12 & 4 & 0.0001 & 61 \\
male & Cop. attempts & 36.95 & 4 & 0.0001 & 61 \\
female & Flight & 12.38 & 3 & 0.0062 & 59 \\
female & Rejection & 10.51 & 3 & 0.015 & 58 \\
female & Remaining & 10.36 & 3 & 0.016 & 59 \\
\hline
\end{tabular}

For definitions of behaviour see text. $\mathrm{df}=$ degrees of freedom. $\mathrm{N}=$ number of fish tested.

Female behaviour.

Normal gynogens respond to male-like behaviour of masculinized gynogens in a way typical for females of the genus. Because of their dependence on male sperm, gynogens have to be able to recognize males. Gynogens even use an active mating tactic and try to intercept matings of P. mexicana (Schlupp et al., 1991). Although H-tests indicated significant differences between the groups (Table 3 ) a pairwise comparison revealed a significant difference only between $F_{1}$-females and $P$. mexicana females in 'Flight' (Fig. 4) and values close to significance in a few more cases. All other comparisons showed no significant differences. Apparently, the $\mathrm{H}$-test provides a less conservative statistical measure than the pairwise comparisons (Bortz et al., 1990). We used Mann-Whitney U-tests to seek for differences between the female reactions to masculinized gynogens and hormone-males. No significant differences were found $(z=-1.65$, $0.36,0$ for 'Flight', 'Rejection' and 'Remaining' resp. all $\mathrm{p}>0.05$ ). All this indicates that normal gynogens recognize masculinized gynogens as 'males'.

DNA-fingerprinting.

DNA-fingerprinting analysis was performed to investigate whether masculinized gynogens constitute a specific clone different from the phenotypically normal gynogens within our fish population or whether the masculinized gynogens might be aneuploid hybrids with the black molly males and not possessing or not expressing the pigmentation genes. Using two different restriction enzymes for DNA digestion and several different oligonucleotide probes, identical fingerprints were obtained for masculinized gynogens and normal gynogens (Fig. 5). 


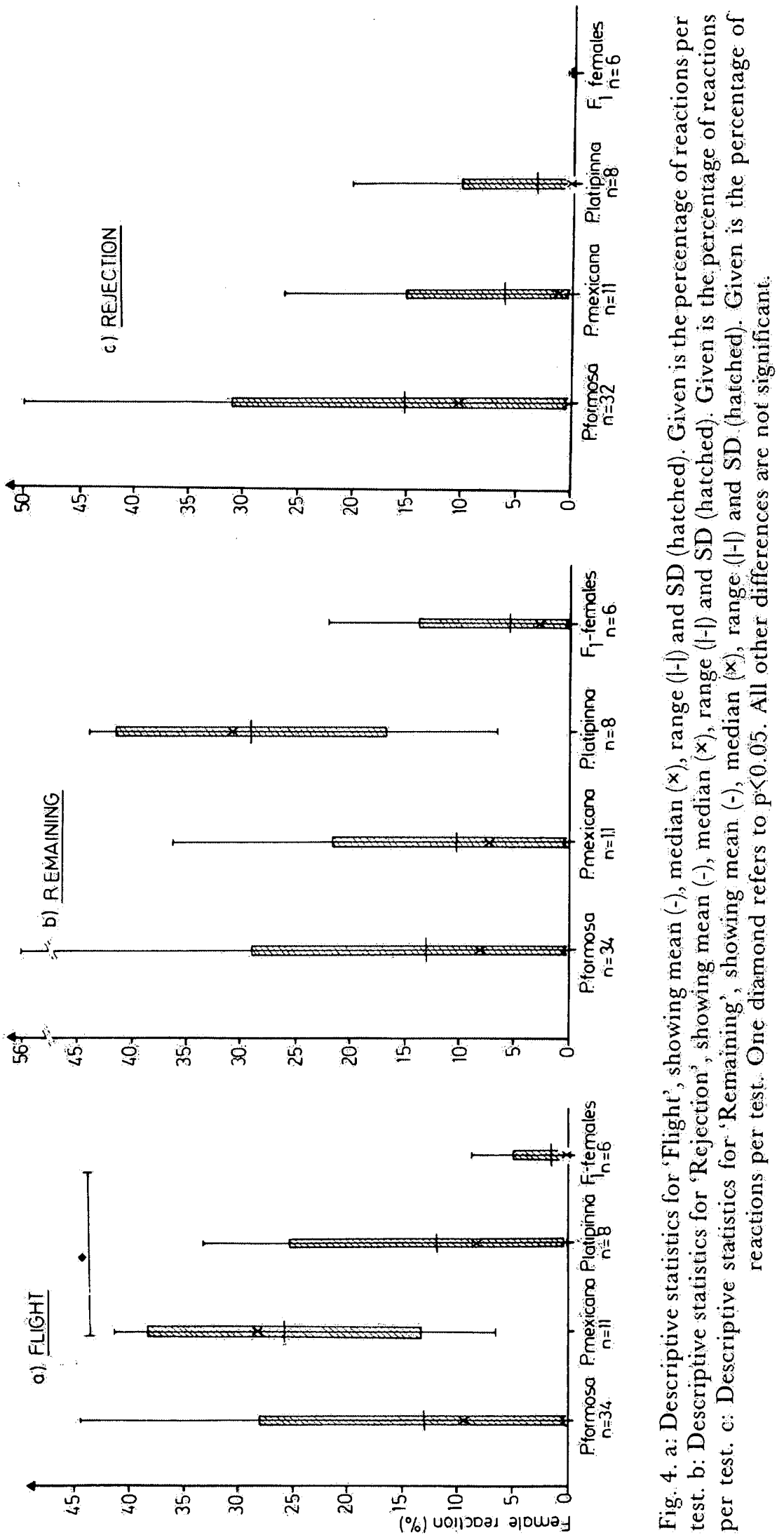




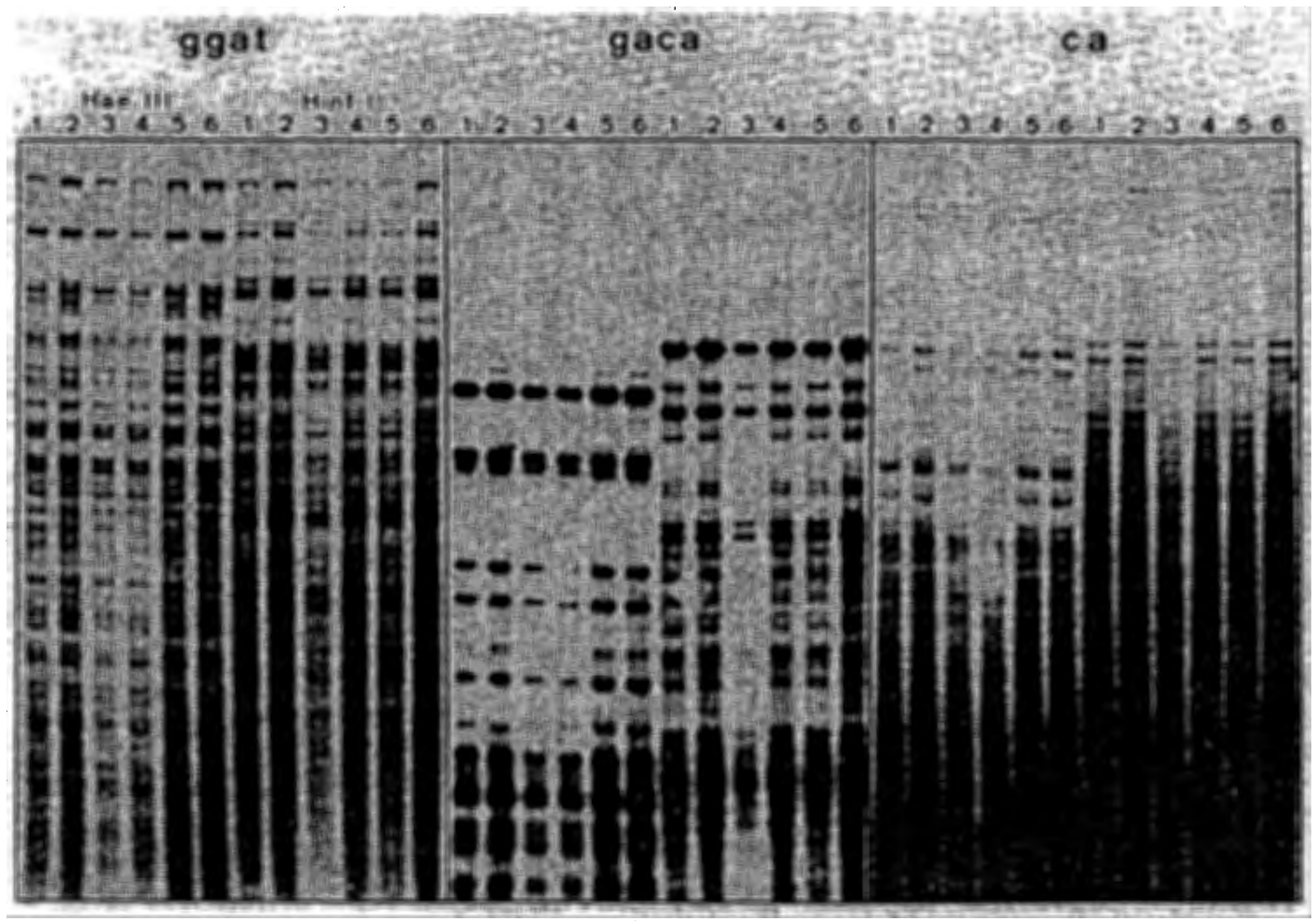

Fig. 5. DNA-fingerprints of masculinized gynogens (1-3) and normal gynogens (4-6) of Poecilia formosa obtained with Hae III and Hinf I digested DNA hybridized to the (GGAT) ${ }_{4}$, $(\mathrm{GACA})_{4}$ and $(\mathrm{CA})_{8}$ probes. The overall identity of the patterns demonstrates the clonal origin and genetic identity of both phenotypic classes. Differences in band intensity are due to loading differences in the DNA amount.

Research of inducing factors.

The fact that masculinized gynogens and typical gynogens are members of the same clone indicates that factors as yet unknown are responsible for masculinization. A temperature effect alone, as suggested by HuBBs (1964) is unlikely, because in a second clone of $P$. formosa masculinized gynogens never occurred, although housing conditions were identical. Temperature may, however, interact with other factors. Free testosterone above a concentration of $10^{-9} \mathrm{M}$ in the aquarium water can be excluded. Females of Girardinus metallicus, which respond extraordinary sensitively to exogenous androgenes, retained the female phenotype when kept in stock tanks with $P$. formosa.

Research of possible effects.

In preliminary experiments we tried to evaluate the effects of masculinized gynogens. $P$. formosa gynogens that were kept for six months with 
masculinized gynogens did not produce offspring ( $\mathrm{N}=4$ replicates). $P$. formosa kept with a male black molly which gonopodium had been clipped did not have offspring either ( $\mathrm{N}=2$ replicates), although sexual behaviour was present. Untreated controles i.e. black molly males with gonopodium $(\mathrm{N}=2$ replicates) had offspring. This suggests that copulation and sperm is actually needed: the presence of a courting male alone is not sufficient a trigger embryogenesis.

Masculinized gynogens never had offspring during the past two years, although kept in stock tanks with black molly males.

\section{Discussion}

Masculinized gynogens and hormone-males are remarkably similar in behaviour. Clonal identity of masculinized gynogens and normal gynogens, as demonstrated by DNA-fingerprinting, shows that the genes coding for male traits in this all-female fish are remarkably stable and remained functionally intact, as also demonstrated by hormonally induced males (see Schartl et al, 1991). Assuming a single hybridisation event that led to $P$. formosa (Schartl et al., 1991), the probable age of $P$. formosa is approx. 10000 years (Darnell \& Abramoff, 1968; Schartl et al., 1991). This period is by far shorter than the 47 million years calculated by OrNo (1985) as the half time for functionality of dispensable alleles. Both the results on masculinized gynogens and those on testosterone treated individuals are in agreement with OHNo's (1985) findings. Both masculinized gynogens and normal gynogens are members of the same clone, indicating that masculinized gynogens arise due to an as yet unknown stimulus. Free testosterone and temperature alone are unlikely to cause the masculinization. Masculinized gynogens furthermore demonstrate that several male traits can be expressed in an allfemale species without experimental manipulation.

The sexual behaviour of masculinized gynogens comprises the typical elements of male behaviour of the parental species. Copulatory behaviour is modified, apparently because of the inability to move the gonopodium. This may be due to the lack of a muscle that moves the gonopodium sidewards.

Using mtDNA analysis Avise et al. (1991) demonstrated that $P$. mexicana is likely to be the female and $P$. latipinna to be the male ancestor of $P$. formosa. Courtship display as known from $P$. latipinna is missing in masculinized gynogens, hormone-males and $\mathrm{F}_{1}$-males. This does not necessarily mean that these males are unable to show this behaviour. It is 
possible that larger males would court. In P. latipinna it depends on a male's relative size within a population whether a male courts or not, and only the largest do so (Parzefall, 1969; FarR et al., 1986; Travis \& WOODWARD, 1989). On the other hand, it is possible that the genetic information for courtship display is lacking. In hybrids of $P$. mexicana and Poecilia velifera, a species closely related to $P$. latipinna, courtship was present in nearly all $F_{1}$-males (Parzefall, 1989).

The $\mathrm{F}_{1}$-hybrids we used were not intermediate in the examined behaviour patterns. Meristic characteristics, however, are intermediate (Schartl et al., 1991). They were clearly gonochoristic and statistically not different from the parental species. All reported attempts to produce a gynogenetic strain by crossing $P$. latipinna and $P$. mexicana (rev. TURner, 1982) resulted in such gonochoristic hybrids.

Individuals of $P$. formosa that appeared to be males have occasionally been reported previously (Table 1 ). Only two such individuals proved to be able to trigger embryogenesis in P. formosa females and 'fathered' some offspring. One of these males was probably a male of the gonochoristic species Poecilia sphenops (see Haskins et al., 1960; HuBBs, 1964), so that only one case of an apparently functional male (Darnell \& Abramoff, 1968) appears to be reliable. This indicates, however, that masculinized gynogens may occur in nature and play a yet unknown role in the breeding complexes related to $P$. formosa.

In our experiments masculinized gynogens failed to induce embryogenesis in normal gynogens. Testosterone treatment of $P$. formosa, however, was able to change the gonadal sex from female to male (TURNER \& Steeves, 1989; Schartl et al., 1991). These findings, together with the findings mentioned above, indicate that there is at least the possibility that functional males might occur, perhaps leading to a new gonochoristic species, as reported in the genus Poeciliopsis by VRIJEnhoek (1989).

For several reasons parthenogenesis is thought to be disadvantageous in the long run (see Maynard Smith, 1982; Bell, 1982; Trivers, 1985), so that the evolution of functional males might be a promising way out of the ecological constraints a unisexual species has to tackle. This, however, has not yet happened and it remains an open question whether the reported pseudomale behaviour is adaptive or not and what the underlying mechanisms might be.

Pseudosexual behaviour (sensu CREws, 1982, 1987, 1988, 1989) is a rare phenomenon associated with unisexuality in vertebrates. Its evolutionary origin and adaptive significance has been demonstrated in the parthenogenetic reptiles Cnemidophorus uniparens (see CREws, 1989) and Lep- 
idodactylus lugubris (WERNER, 1980; ZAWORSKI, 1987). Masculinized gynogens of $P$. formosa not only exhibit male-like behaviour but also male secondary sexual characteristics in body shape, colouration and, most important, the complicated copulation apparatus, the gonopodium (Figs. $1,2)$. As far as we know, $P$. formosa is the first unisexual fish species showing this type of behaviour. P. formosa also is the first gynogenetic species showing pseudosexual behaviour. Up to now, however, neither evolutionary origin nor adaptive significance is clear in $P$. formosa.

\section{References}

Avise, J. C. , Trexler, J. C., Travis, J. \& Nelson, W. S. (1991). Poecilia mexicana is the recent female parent of the unisexual fish $P$. formosa. - Evolution 45, p. 1530-1533.

Balsano, J. S., Rasch, E. M. \& Monaco, P. J. (1989). The evolutionary ecology of Poecilia formosa and its triploid associate. - In: Ecology and evolution of livebearing fishes (Poeciliidae) (G. K. Meffe \& F. F. Snelson JR., eds). Prentice Hall, New Jersey, p. 277-298.

Bell, G. (1982). The masterpiece of nature. - Croom Helm, London.

Bortz, J., Lienert, G. A. \& Boennke, K. (1990). Verteilungsfreie Methoden in der Biostatistik. - Springer Verlag, Berlin.

Crews, D. (1982). On the origin sexual behaviour. Psychoneuroendocr. 7, p. 259-270.

- (1987). Courtship in unisexual lizards: a model for brain evolution. - Scientific American, 255 (12), p. 116-121.

- (1988). The problem with gender. - Psychobiology 16, p. 321-334.

- (1989). Unisexual organisms as model systems in research in behavioral neurosciences. - In: Evolution and ecology of unisexueal vertebrates, (R. M. DAWLEY \& J. P. Bogart, eds). Bull. 466 New York State Museum, Albany, New York, p. 132-143.

Darnell, R. M. \& Abramoff, P. (1968). Distribution of the gynogenetic fish, Poecilia formosa, with remarks on the evolution of the species. - Copeia 1968, p. 354-361.

Dzwillo, M. (1962). Einflu $\beta$ von Methyltestosteron auf die Aktivierung sekundärer Geschlechtsmerkmale über den arttypischen Ausbildungsgrad hinaus (Untersuchungen an xiphophorinen Zahnkarpfen). - Verh. Dt. Zool. Ges. Wien, p. 152-159.

FARR, J. A., Travis, J. \& Trexler, J. C. (1986). Behavioural allometry and interdemic variation in sexual behavior of the sailfin molly, Poecilia latipinna (Pisces: Poeciliidae). - Anim. Behav. 34, p. 497-509.

Goy, R. W. \& Roy, M. (1991). Heterotypical sexual behaviour in female mammals. - In: Heterotypical behaviour in man and animals, (M. HaUgh, P. F. Brain \& C. Aron, eds). Chapman \& Hall, London.

Haskins, C. P., Haskins, E. F. \& Hewitt, R. E. (1960). Pseudogamy as an evolutionary factor in the poecilid fish Mollienesia formosa. - Evolution 14, p. 473-483.

Hubss, C. L. \& Hubbs, L. C. (1932). Apparent parthenogenesis in nature in a form of fish of hybrid origin. - Science 76, p. 628-630.

Hubbs, C. (1964). Interactions between bisexual fish species and its gynogenetic sexual parasite. - Bull. Tex. Mem. Mus. 8, p. 1-72.

- -, Drewry, G. E. \& Warburton, B. (1959). Occurence and morphology of a phenotypic male of a gynogenetic fish. - Science 129, p. 1227-1229.

Kallman, K. D. (1962). Population genetics of the gynogenetic teleost Mollienesia formosa (GIRARD). - Evolution 16, p. 497-504.

Maynard Smith, J. (1978). The evolution of sex. - Cambridge University Press, Cambrigdge. 
Miller, R. R. (1983). Checklist and key to the mollies of Mexico (Pisces: Poeciliidae: Poecilia, subgenus Mollienesia). - Copeia 1983, p. 817-822.

Nanda, I., Feichtinger, W., Schmid, M, Schröder, J. H., Zischler, H. \& Epplen, J. T. (1990). Simple repetitive sequences are associated with differentiation of sex chromosomes in the guppy fish. - J. Mol. Evol. 30, p. 456-462.

Онмо (1985). Dispensable genes. - Trends Genet. 1, p. 160-164.

Parzefall, J. (1969). Zur vergleichenden Ethologie verschiedener Mollienesia Arten einschliesslich einer Höhlenform von $M$. sphenops. - Behaviour 33, p. 1-37.

- (1973). Attraction and sexual cycle of poeciliids. - In: Genetics and mutagenesis of fish, (J. H. Schröder, ed.). Springer Verlag, Berlin, p. 177-183.

- (1989). Sexual and aggressive behaviour in species hybrids of Poecilia mexicana and Poecilia velifera (Pisces, Poeciliidae). - Ethology 82, p. 101-115.

Rasch, E. M. \& Balsano, J. S. (1989). Trihybrids related to the unisexual molly fish, Poecilia formosa. - In: Evolution and ecology of unisexual vertebrates, (R. M. DAwLEY \& J. P. Bogart, eds). Bull. 466 New York State Museum, Albany, New York, p. 252-267.

- -, Prehn, L. M. \& Rasch, R. M. (1970). Cytogenetic studies of Poecilia (Picsces) II. Triploidy and DNA levels in naturaly occuring populations associated with the gynogenetic teleost Poecilia formosa (GIRARD). - Chromosoma, Berl. 31, p. 18-40.

Schartl, A., Scharte, M. \& Anders, F. (1982). Promotion and regression of neoplasia by testosterone-promoted cell differentiation in Xiphophorus and Girardinus. - In: Carcinogenesis, Vol. 7, (Hecker et al., eds). Raven Press, New York, p. 427-434.

Scharte, M. (1988). A sex chromosomal restriction - fragment - length marker linked to melanoma-determinating Tu loci in Xiphophorus. - Genetics 119, p. 679-685.

- -, Schlupp, I., Schartl, A., Meyer, M. K., Nanda, I., Schmid, M., Epplen, J. T. \& Parzefall, J. (1991). On the stability of dispensable constituents of the eukaryotic genome: Stability of coding sequences versus truly hypervariable sequences in a clonal vertebrate, the Amazon molly, Poecilia formosa. - Proc. Natl. Acad. Sci. U.S.A. 88, p. 8759-8763.

Schlupp, I., Parzefall, J. \& Schartl, M. (1991). Male mate choice in unisexual/bisexual breeding complexes of Poecilia (Teleostei: Poeciliidae). - Ethology 88, p. 215-222.

Schultz, R. J. \& Kallman, K. D. (1968). Triploid hybrids between the all-female teleost Poecilia formosa and Poecilia sphenops. - Nature 219, p. 280-282.

Travis, J. \& Woodward, B. D. (1989). Social context and courtship flexibility in male sailfin mollies, Poecilia latipinna (Pisces: Poeciliidae). - Anim. Behav. 38, p. $1001-1011$.

Trivers, R. (1985). Social evolution. - Benjamin/Cummings, Menlo Park, California.

Turner, B. J. (1982). The evolutionary genetics of a unisexual fish, Poecilia formosa. - In: Mechanisms of speciation, (C. BARIgozzI, ed.). Alan R. Liss, New York, p. 265-305.

- - \& Steeves III., H. R. (1989). Induction of spermatogenesis in an all-female fish species by treatment with an exogenous androgen. - In: Evolution and ecology of unisexual vertebrates, (R. M. Dawley \& J. P. Bogart, eds). Bull. 466 New York State Museum, Albany, New York, p. 113-122.

VRIJenhoek, R. C. (1989). Genetic and ecological constraints on the origins and establishment of unisexual vertebrates. - In: Evolution and ecology of unisexual vertebrates, (R. M. Dawley \& J. P. Bogart, eds). Bull. 4666, New York State Museum, Albany, New York, p. 24-31.

- -, Dawley, R. M., Cole, C. J. \& Bogart, J. P. (1989). A list of known unisexual vertebrates. - In: Evolution and ecology of unisexual vertebrates, (R. M. DAwLEY \& J. P. Bogart, eds). Bull. 466 New York State Museum, Albany, New York, p. 19-23.

WERNER, Y. L. (1980). Apparent homosexual behaviour in an all-female population of a lizard, Lepidactylus lugubris, and its probable interpretion. - Z . Tierpsychol. 54, p. 144-150.

ZaWORSKI, J. P. (1987). Observations on unusual behavior in the parthenogenetic gecko, Lepidodactylus lugubris, Fitzinger. - Bull. Chi. Herpet. Soc. 22, p. 76. 


\section{Zusammenfassung}

Pseudosexualverhalten ist ein seltenes Phänomen. Es kommt bei unisexuellen Vertebraten vor. Bei der gynogenetischen Weibchenart Poecilia formosa treten gelegentlich Individuen auf, deren Habitus und Verhalten demjenigen von Männchen nahe verwandter gonochoristischer Arten entspricht. Mittels genetischem Fingerabdruck läßt sich zeigen, da $\beta$ diese Pseudomännchen aus demselben Klon wie normale $P$. formosa stammen. Das Verhalten dieser Pseudomännchen wird beschrieben und mit dem von Männchen der Arten $P$. mexicana, P. latipinna, deren Hybriden und durch Androgenbehandlung vermännlichter Individuen von $P$. formosa verglichen. Zwischen den Pseudomännchen und den androgenbehandelten Tieren bestanden keine statistisch signifikanten Unterschiede. Auch zwischen den gonochronistischen $P$. mexicana und $P$. latipinna bestanden keine statistisch signifikanten Unterschiede, während zwischen unisexuellen und gonochoristischen Arten Unterschiede bestehen. Mögliche Ursachen und Effekte der Vermännlichung werden diskutiert. 